\title{
Joint hypermobility in girls with idiopathic scoliosis: relation with age, curve pattern and curve size
}

\author{
Dariusz Czaprowski ${ }^{*}$ Tomasz Kotwicki, Paulina Pawłowska, Łukasz Stoliński, Mateusz Kozinoga, Piotr Janusz \\ From 10th International Conference on Conservative Management of Spinal Deformities - SOSORT 2013 \\ Annual Meeting \\ Chicago, IL, USA. 8-11 May 2013
}

\section{Background}

A complete musculoskeletal examination should include the specific tests to detect hypermobile individuals, especially when physiotherapy affecting joint mobility is planned. Joint hypermobility $(\mathrm{JH})$ is defined as an excessive range of motion of joints, taking into consideration the subject's gender, age, and ethnic background [1].

\section{Purpose}

The goal of this study was to assess the prevalence of $\mathrm{JH}$ in girls with idiopathic scoliosis (IS), taking into account the age, curve pattern and curve size.

\section{Methods}

The study group included 147 Caucasian girls with IS, aged 9-18 years (mean $13.6 \pm 2.2$ ), Cobb angle range $11^{\circ}$ $65^{\circ}$, mean $27.9 \pm 11.9$, comprising 42 single thoracic, 31 single lumbar and 74 double curve scoliosis. According to the Cobb angle, there were 70 mild $\left(10-24^{\circ}\right), 54$ moderate $\left(25-40^{\circ}\right)$ and 23 severe $\left(>45^{\circ}\right)$ curves. The control group included 147 girls aged 9-18 years (mean $13.1 \pm .3$ ), selected at random from the group of 300 girls free of IS (angle of trunk rotation $<5^{\circ}$ ). The presence of $\mathrm{JH}$ was assessed with the 9-point Beighton scale [1], using the cutoff $\geq 5$ points.

\section{Results}

$\mathrm{JH}$ was diagnosed in $24.5 \%$ of IS girls, whilst in the control group, it was diagnosed in $15.1 \%(\mathrm{p}=0.04)$. The prevalence of $\mathrm{JH}$ was significantly $(\mathrm{p}=0.03$ ) lower in IS girls aged 16-18 years in comparison to younger individuals (9-15). There was no difference regarding JH occurrence among girls with mild, moderate and severe scoliosis

* Correspondence: dariusz.czaprowski@interia.pl

Department of Physiotherapy, Józef Rusiecki University College, Olsztyn, Poland; Rehasport Clinic, Poznań, Poland $(\mathrm{p}=0.8)$. No significant differences in $\mathrm{JH}$ prevalence was observed among girls with single thoracic, single lumbar and double curve scoliosis $(\mathrm{p}=0.68)$. The number of vertebrae within curvature did not influence the prevalence of $\mathrm{JH}(\mathrm{p}=0.13)$.

\section{Conclusions and discussion}

$\mathrm{JH}$ appeared more often in IS girls than in healthy controls. Its prevalence decreased with age. No relation between $\mathrm{JH}$ prevalence and curve pattern, curve size or number of vertebrae within curvature was found.

Published: 18 September 2013

Reference

1. Murray KJ: Hypermobility disorders in children and adolescents. Best Pract Res Cl Rh 2006, 20:329-51.

\section{doi:10.1186/1748-7161-8-S2-P2}

Cite this article as: Czaprowski et al:: Joint hypermobility in girls with idiopathic scoliosis: relation with age, curve pattern and curve size. Scoliosis 2013 8(Suppl 2):P2.

Submit your next manuscript to BioMed Central and take full advantage of:

- Convenient online submission

- Thorough peer review

- No space constraints or color figure charges

- Immediate publication on acceptance

- Inclusion in PubMed, CAS, Scopus and Google Scholar

- Research which is freely available for redistribution
C Biomed Central

(ㄷ) 2013 Czaprowski et al; licensee BioMed Central Ltd. This is an Open Access article distributed under the terms of the Creative Commons Attribution License (http://creativecommons.org/licenses/by/2.0), which permits unrestricted use, distribution, and reproduction in any medium, provided the original work is properly cited. 